\title{
The Local Government Strategies in Building Halal Tourism in Bener Meriah Regency
}

\author{
Rahmat Yanidin*1 Muhammad Bin Abubakar ${ }^{2}$ \& M. Akmal ${ }^{2}$ \\ 1Student of the Master Program of Public Administration, Universitas Malikussaleh, Aceh Utara, Indonesia \\ 2Master Program of Public Administration, Universitas Malikussaleh, Aceh Utara, Indonesia \\ *Corresponding Author: rahmatyanidin@gmail.com
}

\begin{abstract}
This study aims to determine the strategy of the Local Government of Bener Meriah Regency, in this case, what the Tourism Office has done in building halal tourism in Bener Meriah Regency. This research is a descriptive study with the support of qualitative data. Data collection techniques were obtained through in-depth interviews and documentation studies. The determination of informants was obtained by purposive sampling technique. From the research results, it was found that the Regional Government in building halal tourism in Bener Meriah Regency has not been optimal and is fixing everything related to the concept of halal tourism. Qanun Number 06 of 2018 concerning the Medium-Term Regional Government Plan for 2017-2022 through the first mission of the Regent of Bener Meriah Regency has set the policy direction for the development of the concept of halal tourism in Bener Meriah Regency. The sector that is carried out related to the concept of halal tourism has not touched anything in Bener Meriah Regency. The stakeholder understanding of the concept of halal tourism in local government policies is still limited to building tourism objects in Bener Meriah Regency so that in the future there will be evaluations related to policy directions regarding the concept of tourism halal in Bener Meriah Regency.
\end{abstract}

Keywords: strategy; local government; halal tourism

\section{Introduction}

In their work, halal tourism has been developed by many countries whose residents are not even Muslim, for example, such as Australia, Japan, Thailand, New Zealand. The high demand for halal tourism makes the government in the aforementioned countries motivated to promote halal tourism so that the concept of halal tourism can be fulfilled, making it a tourist attraction capable of meeting the needs of tourists who come to that country.

Halal tourism objects are not only concerned with places of worship, they also include halal lodging, halal restaurants, halal spas, halal cafes, and many more that must be maintained in this halal tourism promotion. Halal in a statement does not necessarily make visitors believe that the products or types of services they use are halal, the government must believe in the existence of certification from the Indonesian Ulema Council (MUI) and related institutions that collaborate in implementing this halal tourism promotion.

Indonesia has enormous potential in the field of tourism. The beauty and abundant natural wealth, various ethnicities, languages, cultures, and local wisdom inherent in the Indonesian population make anyone present on the archipelago will be captivated by the charm of tourism in Indonesia. The Ministry of Tourism's report in August alone The visits of foreign tourists to Indonesia through all entrances in August 2019 totaled 1,555,436 visits or an increase of 2.94\% compared to the same period in August 2018 which totaled 1,551,021 visits. Based on nationality, the number of foreign tourist visits in August 2019 recorded the highest number of foreign tourists visiting, namely: Malaysia with 263,318 visits, China with 193,407 visits, Singapore with 174,097 visits, Australia with 131,372 visits, and Timor Leste with 109,649 visits. Meanwhile, the growth in the number of foreign tourists in August 2019 when compared to August 2018 was recorded as having the highest growth, namely Egypt at 34.44\%, the United States at $29.66 \%$, Russia at 28.70\%, Malaysia at $25.30 \%$, and Brazil $22.47 \%$. The potential for foreign tourists visiting Indonesia is very significant for the contribution of foreign exchange contributors to the Unitary State of the Republic of Indonesia.

One province that has a very distinctive tourism charm in Indonesia, namely Aceh. Areas that are 
attached to Islamic sharia are so thick that it is not surprising that it is a very interesting issue when discussing Islamic sharia both in terms of its application and studies that concern all aspects of the life of the Acehnese people. The potential for halal tourism in Aceh is so tantalizing how does Aceh have such enchanting natural charm, culture, culinary, and most importantly, the taste of Gayo coffee which has long been worldwide.

Seven Aceh tourism objects were nominated for Anugerah Pesona Indonesia in 2019, the seven categories of tourist objects that were nominated, namely, Bireuen Sate Apalah Geurugok Regency which was nominated for traditional food, Rabbani Wahid was nominated for cultural attractions, Langsa City Mangrove Forest Park entered ecotourism nominees, Gayo Lues Kerawang Gayo District Cinderamata Nomination, Sabang Km Zero City was nominated for a unique destination, Bener Meriah Regency Tourism Object Tensaran Bidin Waterfall was nominated for hidden paradise and Sabang City with Sabang Marine was nominated for the Tourism Festival. Anugerah Pariwisata Indonesia (API) is a series of annual activities held to generate public appreciation for Indonesian tourism.

The enormous potential in Bener Meriah Regency allows this area to increase the standard of living of the community so that it has an impact on economic growth. Several tourist attractions are visited when we come to this district with cool air including Tensaran Bidin waterfall, Reje Ilang waterfall, Bintang Musara waterfall, Datu Beru grave, hot spring in Bandar Lampung, lut kucak lake, rafting in samar refineries, jungle radio monument and peak burni telong.

Qanun Number: 6/2018 concerning the Bener Meriah District Medium-Term Development Plan (RPJMD) 2017-2022 Chapter II Medium-Term Regional Development Plan in Chapter VII Development Funding Framework and the Bener Meriah Regency Apparatus Program contained in the first mission of the Bener Meriah Regency Government "Realizing the implementation of Islam in kaffah" to strengthen the order of religious life, harmony, and community obedience in carrying out complete religious guidance (kâffah) in the effort of the spirit of faith and devotion to Allah SWT as the main foundation in governance and community life. The goal of developing Islamic tourism and halal tourism destinations and strategies of developing Islamic culture, Islamic tourism, and halal tourism policies for developing Islamic culture, Islamic tourism, and halal tourism with the "Tourism Destination Development Program" and "Tourism Promotion Promotion Program". Tourism Destination Development Program in 2018 Funding Plan of Rp. 1,242,363,000, -, in 2019 2,073,917,000, - and in 2020 amounting to Rp. 3,093,306,000,--

For the "Tourism Promotion Enhancement Program" the funding plan for 2018 is Rp. 1,490,836,000, - in 2019 Rp. 2,488,701,000, - and in 2020 Rp. 3,711,682,000, -.

The huge budget for the "Tourism Destination Development Program" and the "Tourism Promotion Promotion Program" actually shows the seriousness of the local government in developing a halal tourism policy in Bener Meriah Regency. The Bener Meriah Regency Tourism Office has made efforts in realizing this policy by building several tourism destinations but has not yet described the halal tourist destinations referred to in local government policies. As an area that has tremendous potential, Bener Meriah Regency must clean up and prepare and develop halal tourism is a tourist visit activity with tourism destinations and industries that prepare product, service, and tourism management facilities that meet the elements of sharia. Another purpose of halal tourism is a form of culture-based tourism that emphasizes the values and norms of Islamic Sharia as its basic foundation (Widagdyo, 2015). The value of Islamic sharia is a belief and belief held by Muslims, especially the community and the Bener Meriah district government as a reference in building tourism activities.

\section{Formulation of the problem}

1. How are the local government efforts to develop halal tourism in Bener Meriah Regency ?.

2. What are the obstacles faced by the Regional Government in developing halal tourism in Bener Meriah Regency?.

3. What sectors are already running in the concept of halal tourism in the Bener Meriah Regency?.

\section{Literature Review}

The theory is an important foundation in understanding, interpreting, and interpreting data, therefore the authors use several theories as follows:

\section{Definition of Tourism}

According to linguists, the word tourism comes from the Sanskrit language which consists of two syllables, namely pari and tourist. Pari means all, all, and full. Tourism means to travel. Thus tourism can be interpreted as a full journey, namely departing from a place, heading to and stopping, at someplace, and returning to its original place. The term "tourism" is said to have been used for the first time by President Soekarno in a conversation equivalent to the foreign term tourism. According to Soekadijo, tourism is all 
activities in society related to tourists.

All activities of hotel development, restoration of cultural heritage, creation of recreation centers, organizing tourism fairs, providing transportation, and so on can all be called tourism activities as long as these activities can all be expected that tourists will come (Soekadijo, 1997: 2).

Meanwhile, AJ Burkart and S. Medlik stated that "Tourism, past, present, and future", reads "tourism means the temporary (and) short-term movement of people to destinations outside the places where they usually live and work, and their activities while living in the destination places (Soekadijo, 1997: 3)

Hunziger and Krapf from Switzerland, define tourism as "the whole network and symptoms associated with the stay of foreigners in a place, provided that they do not stay there to do important work that provides permanent or temporary benefits." This consists of two parts. The first part (overall .... symptoms related to the stay of foreigners) is the definition of tourism as explained above. The definition that is generally considered good in its second part defines 'temporary residence' or 'not staying' economically and defines as 'tourists do not do important work that gives profit' (Soekadijo, 1997: 12).

Norval, a British economist, also gives an economic meaning to the notion of "immovability" and assumes that what is defined is only foreign tourists. Therefore the definition says that a tourist is any person who comes from a foreign country, whose reason is not to stay or to work there regularly, and who in the country where he lives temporarily spends the money he gets elsewhere (Soekadijo, 1997: 13 ).

Based on these opinions and experts, the writer can give the understanding that tourism is a trip that is carried out temporarily from one place to another which has tourist objects and attractions to be enjoyed as a recreation or entertainment to get physical and spiritual satisfaction.

\section{Sharia/Islamic Tourism}

The definition of Islamic tourism is an activity that is supported by various facilities and services provided by the community, businessmen, government, and local governments that comply with Islamic law 14 (Kemenpar, 2012). The facilities and services provided are no different from other public facilities, it's just that the facilities and services provided do not conflict with Islamic values. So that the Muslim community can enjoy the facilities and services provided by the community freely. Islamic tourism has been introduced since 2000 from the discussion of the Organization of the Islamic Conference (OIC) meeting.

Islamic tourism is a tourist demand based on the lifestyle of Muslim tourists during the holidays. In addition, Islamic tourism is tourism that is flexible, rational, simple, and balanced.

This tourism aims to motivate tourists to get happiness and blessings from Allah SWT (Munirah, 2012 in Dharma, 2017). A part from the term sharia tourism, it is also known as Halal tourism or Halal tourism.

At the launch of sharia tourism which coincided with the 2013 Indonesia Halal Expo (Index) and the Global Halal Forum which was held on 30 October - 2 November 2013 at Semeru Room, 6th Floor, Commercial Center Building, JIExpo (PRJ), Kemayoran, Central Jakarta, Wednesday (30/10/2013), President of the Islamic Nutrition Council of America, Muhammad Munir Caudry, said that "Halal tourism is a new concept of tourism. This is not religious tourism like Umrah and performing the pilgrimage.

Halal tourism is tourism that caters to holidays, by adjusting the holiday style according to the needs and demands of a Muslim traveler. In this case, hotels that adhere to sharia principles do not serve alcohol and have separate swimming pools and spa facilities for men and women (Wuryasti, 2013).

Based on the above definition, the concept of sharia that does not violate or conflict with sharia values and ethics is related to the concept of halal and haram in Islam. Halal is defined as justified, while haram is defined as prohibited. The concept of halal can be seen from two perspectives, namely a religious perspective and an industrial perspective. What is meant by a religious perspective, namely as a law of what foods can be consumed by Muslim consumers? This brings the consequences of consumer protection from an industry perspective.

For food producers, this halal concept can be interpreted as a business opportunity. For the food industry whose target consumers are mostly Muslims, it is necessary to ensure the halalness of the product will increase its value in the form of intangible value. Examples of food products whose packaging includes a halal label are more attractive to Muslim consumers (Hamzah \& Yudiana, 2015 in the Ministry of Tourism, 2015). According to Sofyan (2012: 33) in the Ministry of Tourism (2015), the definition of sharia tourism is broader than religious tourism, namely tourism based on Islamic sharia values. As recommended by the World Tourism Organization (WTO), consumers of sharia tourism are not only Muslims but also nonMuslims who want to enjoy local wisdom.

\section{Tourism Object}

The definition of tourism objects in Law Number 9 of 1990 concerning tourism, Chapter I Article 4.6 states that tourism objects and tourist attractions are everything that is the target of tourism. Furthermore, Chapter III Article 4 it is stated: 
a. Tourist objects and attractions consist of:

b. Objects and tourist attractions created by God Almighty in the form of natural conditions as well as flora and fauna.

c. Objects and tourist attractions made by humans in the form of museums, ancient relics, historical relics, cultural arts, agro-tourism, water tourism, hunting tours, adventure tours, recreational parks, and entertainment venues.

d. The government determines tourist objects and attractions other than those referred to in paragraph 1 letter b. Oka A. Yoeti (1997) explains that tourism objects are various kinds of things that can be seen, witnessed, done, or felt. Meanwhile, Chafid Fandeli (1995) defines tourism objects as a manifestation of human creation, life system, cultural arts, and national history and places or natural conditions that have an attraction for visiting tourists.

\section{Tourism Development}

Tourism Development The definition of development according to J.S Badudu in the General Indonesian Dictionary, provides a definition of development as a thing, way, or result of developing work. Meanwhile, developing means opening, advancing, advancing, and improving. There are two general guidelines for a good tourism organization, namely cooperation, and coordination between:

a. Officials who sit in organizations at the national, provincial, and local levels

b. Entrepreneurs engaged in the tourism industry, such as travel businesses, lodging businesses. transportation business, recreation, and entertainment sector business, tourism financial institution, souvenir business, and general traders.

c. Non-profit organizations closely related to tourism (eg tourist clubs and clubs, cars).

d. Professional associations in tourism. (Wahab, 1977: 267).

\section{Strategy}

According to Sjafrijal (2009: 291), Strategy is generally defined as a way or tool to achieve goals better and faster. While the notion of the strategy itself changes from time to time, namely:

a. Chandler (1962): strategy as a tool to achieve corporate (institutional) goals in terms of long-term goals, follow-up programs, and resource allocation priorities;

b. Learned, Christenten Guth (1965): strategy as a tool to create competitive advantage;

c. Porter (1985): Strategy as a very important tool to achieve competitive advantage;

d. Hamel and Prahalad (1995) say that strategy is an action that is always increasing and carried out based on the point of view of what customers expect in the future.

According to Makmur (2009: 128), the strategy is an action that influences and determines the success of a program or activity, whether planned or planned by the management. According to Allison (2013: 3), the strategy is a priority or broad overall direction taken by the organization, strategy is also choices about how best to achieve the organization's mission. The strategy is also inseparable from the name of strategy formulation, as stated by Mahmudi (2010: 65), the strategy formulation stage is important in the management control process because errors in formulating strategies will result in organizational misdirection.

\section{Methods}

This study is a descriptive study with a qualitative research approach. Data collection was carried out by interviewing, observing, and reviewing good documentation from books, journals related to the object of research, namely the Bener Meriah Regency Tourism Office.

\section{Results and Discussion}

From the research results, it was found that the regional government in building halal tourism in Bener Meriah Regency found many obstacles. The efforts made by the Tourism Office started from visiting all tourist objects in Bener Meriah Regency, making tourist service facilities, promoting and building tourist facilities and infrastructure. Besides that, it also improves accessibility to tourism objects in Bener Meriah Regency, increases the capacity of Human Resources (HR), especially those directly related to the development of halal tourism, improves the quality of human resources (HR) which includes increasing capabilities such as knowledge, enhancement physical abilities, skills and in the control of existing resources.

However, there are also inhibiting factors in developing halal tourism, namely limited infrastructure, low tourism human resources, low investment and support from interested parties, and the length of stay of tourists is relatively very short. But there are supporting factors, namely: each tourist attraction has a unique, strategic location. Therefore there is a need for more focused coordination, increasing the involvement of the private sector and the community in the development of halal tourism objects, increasing the promotion and 
marketing of halal tourism products, increasing cooperation with various related parties, forming and fostering tourism awareness groups, providing counseling, briefing and an explanation of the importance of halal tourism.

\section{Conclusions}

Several things that can be concluded from the research are: The potential for halal tourism that is being built by the Bener Meriah Regency Government can be developed as a tourist attraction that has a promising future. The potential for halal tourism that is being developed includes Tensaran Bidin Waterfall, Reje Ilang Waterfall, Bintang Musara Waterfall, Datu Beru Tomb, Wih Pesam Hot Spring, Samar Kilang Rafting, Bur Ni Telong Peak, Lut Kucak Lake, Radio Monument Rimba Raya, Bandar Lampahan Hot Spring.

These various potentials are under construction and will be developed as an attraction for halal tourism objects by the Bener Meriah Regency Government and related parties. These empowerment efforts include providing and developing various supporting facilities for halal tourism, improving accessibility to tourist objects and attractions, increasing the capacity of Human Resources (HR), especially those directly related to halal tourism development, increasing halal tourism promotion, and developing institutions that can support the development of halal tourism.

In developing these various potentials, there are several obstacles or obstacles, including the absence of development of tourism awareness groups, low tourist visits, the low concern of local governments, low quality of human resources.

To overcome these obstacles or constraints, strategies are formulated to empower and develop the potential for halal tourism, including increasing and developing types of halal tourism products, improving and increasing accessibility to tourist objects and attractions, increasing promotion and marketing of halal tourism products, increasing cooperation with various parties. related, forming, and fostering tourism awareness groups, providing counseling, direction, and explanation of the importance of tourism for regional development.

The sector that is carried out related to the concept of halal tourism has not touched anything in Bener Meriah Regency. The stakeholder understanding of the concept of halal tourism in local government policies is still limited to building tourism objects in Bener Meriah Regency so that in the future an evaluation will be carried out related to policy directions regarding the concept of tourism halal in Bener Meriah Regency.

\section{Recommendations}

Some suggestions that can be given based on the results of this study are:

The natural and cultural potentials that exist in Bener Meriah Regency need to be empowered and their roles enhanced to support the development of halal tourism in Bener Meriah Regency.

a. To support the development of tourism objects, accessibility to tourist objects and attractions in Bener Meriah Regency needs to be improved.

b. Tourism facilities including accommodation, means of communication, means of transportation, and facilities related to the development of halal tourism need to be improved to provide convenience to both domestic and foreign tourists.

c. Tourist activities that can be carried out by tourists when visiting halal tourism objects and attractions in Bener Meriah Regency need to be developed so that they can extend the length of stay of tourists and can provide a memorable travel experience for tourists.

Increase the participation of interested parties in the development of halal tourism in Bener Meriah Regency to develop regional tourism through the development of various natural and cultural potentials found in Bener Meriah Regency.

\section{References}

Abdul Wahab, Solichin. (1997). Analisis Kebijaksanaan, Dari Formulasi Ke Implementasi Kebijaksanaan

Negara. Penerbit P.T. Bumi Aksara, Jakarta.

Anggara, Sahya.( 2014). Kebijakan Publik. Penerbit CV Pustaka Setia, Bandung.

Depdikbud. (1988). Kamus Besar Bahasa Indonesia. Balai Pustaka. Jakarta.

Fandeli, Chafid. (1997). Dasar-dasar Manajemen Kepariwisataan Alam. Liberty. Yogyakarta.

Islamy, Irfan. (2001). Prinsip-prinsip Perumusan Kebijakan Negara, Cetakan X, Bumi Aksara, Jakarta.

Jones, Charles O. (1996). Pengantar Kebijakan Publik (Public Policy) Terjemahan Ricky Ismanto. Penerbit P.T.

Raja Grafindo Persada, Jakarta.

Kamus Besar Bahasa Indonesia. (2014). Pusat Bahasa Departemen Pendidikan Nasional. Cetakan VII, Edisi IV, 
Penerbit PT Gramedia Pustaka Utama, Jakarta.

Mulyadi, Dedy. (2015). Studi Kebjakan Publik dan Pelayanan Publik. Penerbit Alfabeta, Bandung.

Nugroho D, Riant. (2006). Kebijakan Publik Untuk Negara-Negara Berkembang. Penerbit PT Elex Media Komputindo, Jakarta.

Nurcholis, Hanif. (2007). Teori dan Praktek Pemerintahan dan Otonomi Daerah, Penerbit P.T. Gramedia Widiasarana Indonesia, Jakarta.

Kodhyat H. (1996). Sejarah Pariwisata dan Perkembangannya di Indonesia. Grasindo. Jakarta.

Lubis, Hari dan Husaini, Martani. (2010). Teori-Teori Organisasi. Grasindo. Jakarta.

Miles, Matthew B dan Huberman, A. Michael. (1992). Analisis Data Kualitatif. UI Press. Jakarta.

Moleong, Lexy J. (2002). Metode Penelitian Kualitatif. PT. Remaja Rosdakarya. Bandung.

Pendit, Nyoman S. (1999). Ilmu Pariwisata Sebuah Pengantar Perdana. PT. Pradnya Paramita. Jakarta.

Radiawan, Hari, Hartati, dan Soepomo, Sri Sadah. (1997/1998). Pengembangan Jaringan Ekonomi di Kawasan Pariwisata. CV : Bupara Nugraha. Jakarta.

Sjafrizal. (2009) . Teknik Praktis Penyusunan Perencanaan Pemerintah Daerah. Baduose Media

Soekadijo, R. G. (1997). Anatomi Pariwisata : Memahami Pariwisata Sebagai Sistem Linkage. Gramedia Pustaka Utama. Jakarta.

Spillane, James, J. (1994). Pariwisata Indonesia : Siasat Ekonomi dan Rekayasa Kebudayaan. Kanisius. Yogyakarta.

Sutopo, HB, (2002). Metode Penelitian Kualitatif: Dasar Teori dan Penerapannya dalam Penelitian. UNS Press. Surakarta.

Suwantoro, Gamal. (1997). Dasar-dasar Pariwisata. ANDY. Yogyakarta.

Wahab, Salah dkk, (1997). Pemasaran Pariwisata. PT. Pradnya Paramita. Jakarta.

Yoeti, Oka A, (1990). Pengantar Ilmu Pariwisata. Angkasa. Bandung.

Yoeti, Oka A, (1996). Pemasaran Pariwisata. Angkasa. Bandung.

Yoeti, Oka A, (1997). Perencanaan dan Pengembangan Pariwisata. PT. Pradnya Paramita. Jakarta. 